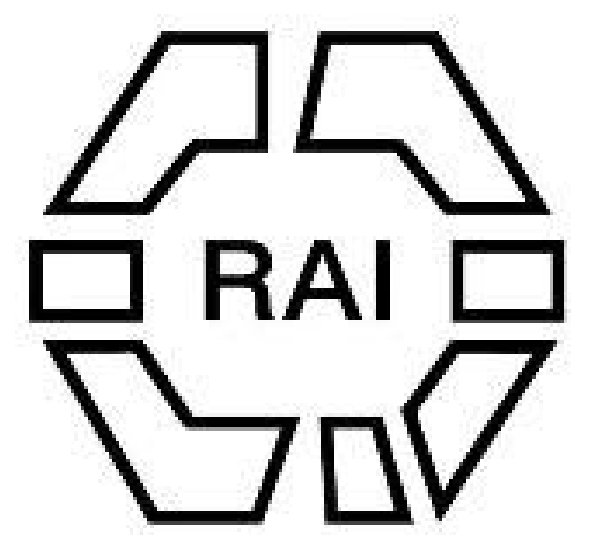

\title{
WILEY
}

\section{Notes on Leueneuwa, or Lord Howe's Group.}

\author{
Author(s): C. M. Woodford
}

Source: Man, Vol. 6 (1906), pp. 133-135

Published by: Royal Anthropological Institute of Great Britain and Ireland

Stable URL: http://www.jstor.org/stable/2788920

Accessed: 27-06-2016 01:05 UTC

Your use of the JSTOR archive indicates your acceptance of the Terms \& Conditions of Use, available at

http://about.jstor.org/terms

JSTOR is a not-for-profit service that helps scholars, researchers, and students discover, use, and build upon a wide range of content in a trusted digital archive. We use information technology and tools to increase productivity and facilitate new forms of scholarship. For more information about JSTOR, please contact support@jstor.org.

Royal Anthropological Institute of Great Britain and Ireland, Wiley are collaborating with JSTOR to digitize, preserve and extend access to Man 
$0.50 \mathrm{~cm}$. wide and $0 \cdot 10 \mathrm{~cm}$. thick. All the large monoliths before mentioned are cut out of diorite, and are shapely, in fact far more so than any I have seen at other ruins in Rhodesia. The smaller monoliths are of granite.

A large number of graves are to be found on the plateau; in fact, they are all around the ruin, though, owing to the undergrowth, I was unable to examine more than those already mentioned.

The graves face any direction, and, apparently, it mattered nothing to the living at that time in which direction they pointed. From the length of the graves the bodies must have lain at full length, though I did not interfere with them. They are covered with heaps of stones of country rock, nearly rounded, weighing on an average about $60 \mathrm{lbs}$. and have the appearance of being water worn.

In conclusion, I cannot but think the building is nothing more or less than a royal tomb, the outside graves being probably those of near relations. I much regret the impossibility of taking photos at present, but, even were the undergrowth and smaller trees cleared away, the enormous trees and their foliage would still keep the place in semi-darkness. The ruin and its surroundings suggests to my mind greater age than any Rhodesian ruin yet reported, and I earnestly hope some well directed work may shortly be done upon it, which work will, no doubt, throw further light on the mysterious ruins of Rhodesia.

E. M. ANDREWS.

\section{Solomon Islands : Lord Howe's Group.}

Woodford.

Notes on Leueneuwa, or Lord Howe's Group. By C. M. Woodford, Resident Commissioner, British Solomon Islands, Local Correspondent of the Anthropological Institute.

This group was discovered by Lemaire and Schouten in 1616, again by Tasman in 1643, and by Captain Hunter in 1791. I myself hoisted the British flag here in 1900 when it was transferred from the possession of Germany to British protection. I visited this group quite lately, for the fourth time, in April last.

Canoes are made of the trunks of large trees which come adrift during the N.W. monsoon, probably from New Ireland.

The natives use the cross weaving loom. I saw it in use. The broken warps are weighted at the ends with small stones to keep them in position.

The group is an atoll and consequently nothing but coral stone exists, but I noticed a few hard basaltic stones used as cooking-stones, which, I was told, had been collected from the roots of drift timber.

The dead are buried ashore in well-kept graveyards. Large hewn coral slabs are erected over the graves, which are covered with pure white sand and are carefully swept every day by the widows.

The tombstone over the grave of the late chief Ouila, who was in power when the protectorate was declared, is about 12 feet high and 3 or 4 feet wide, and his widows, although he has been dead for more than two years, are still living in the neighbourhood of the graveyard and sweep the grave carefully all day.

Turtles are kept in pits dug in the ground near the sea which are full of muddy brackish water and swarm with mosquitos (culex); no anopheles were noticed. The pits are covered with trunks of trees to keep them dark. The unhappy turtles must spend a most wretched life in these pits, but they are kept there for years and are fed on crabs and fish. One or two plates of shell are removed at a time from the living turtle and the plates eventually grow again. I had heard of this twenty years ago, but $I$ never saw the pits until the present visit.

A specimen of Leueneuwa tattooing has already been published (MaN, March 1901, No. 31). That was the common form. A more elaborate pattern is herewith 
reproduced. The women are much more extensively tattoed than the men, but I was not able on this occasion to secure a drawing.

The tattooing "needle," "Makau," is made of the wing bones of the frigate bird "Akaha." The hammer or mallet called "Heli' $i$," is made of coco-nut wood. The colouring medium is made from the charred nut of the Calophyllum inophyllum. Name of tree, "Hakau."

The natives are Polynesians with a strong Micronesian admixture.

Traditions of castaways having arrived from Niutau, Apamama, Miana, Tamana, and Arorai in the Gilbert Group, are preserved.

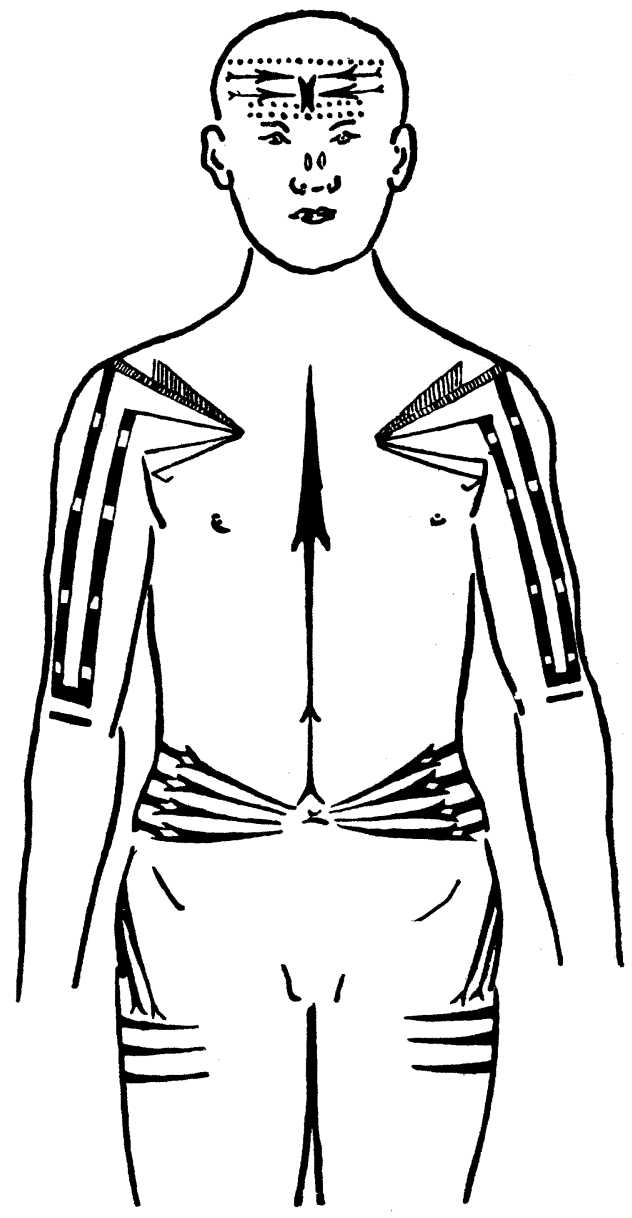

FIG. 1.-MAN OF LEUENEUWA : FRONT VIEW

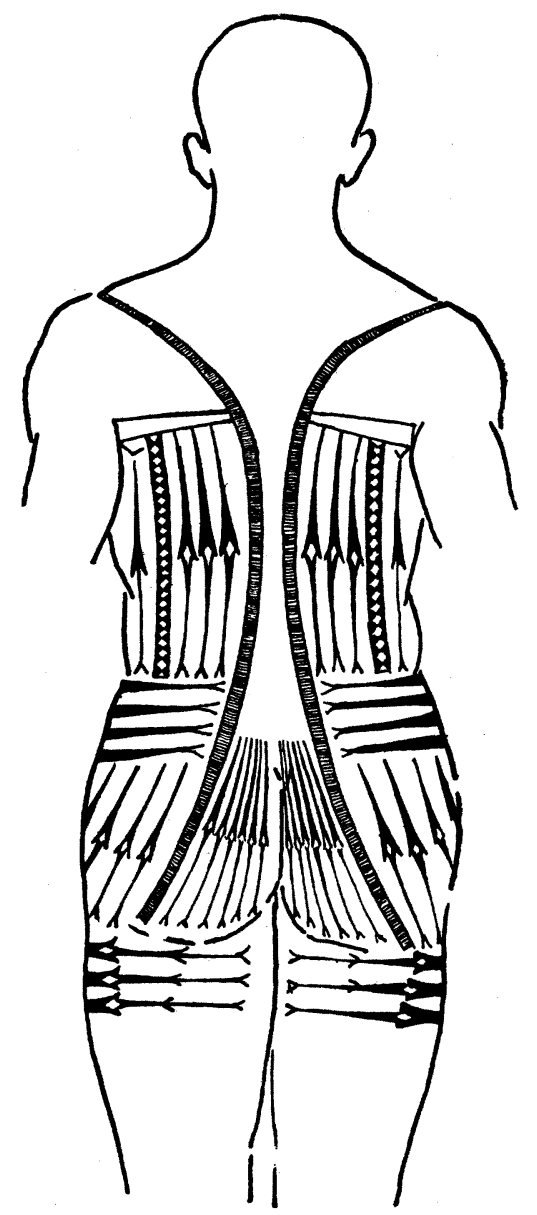

FIG 2.-MAN OF LEUENEUWA : BACK VIEW.

Also the tradition of the arrival of castaways from a very distant island called More-ei. They were said to have been tattooed in small patterns upon the arms and legs. The visit of a canoe from Sikaiana is also remembered as a tradition.

Bogowea, the king of Maiaua, with two women was one of these castaway parties. Another, with two men and two women from Apamama, arrived at the Nuknmanu group (about 60 miles north of Leueneuwa). Three of these afterwards moved to Leueneuwa, and my informant, a man of fifty, remembered seeing one of them, a very old woman, when he was a boy. 
The last castaways, from Tamana (2) and Arorai (2) arrived about twenty-five years ago, and were taken away in the Cristine in 1886. An albino native was observed.

A short list of words in the language of Leueneuwa, or Lord Howe's Group, is appended :-

\begin{tabular}{|c|c|c|c|c|c|}
\hline \multirow{4}{*}{\multicolumn{2}{|c|}{$\begin{array}{l}\text { Ashes } \\
\text { Bad - } \\
\text { Banana } \\
\text { Belly - }\end{array}$}} & \multirow{2}{*}{$\begin{array}{l}\text { - Rehu. } \\
\text { - Faio. }\end{array}$} & Little & - & - Li'i. \\
\hline & & & Louse - & - & - Huku. \\
\hline & \multirow{3}{*}{$\begin{array}{l}- \\
- \\
- \\
-\end{array}$} & Huki. & Man & - & - Kanaka. \\
\hline & & - Manava. & Mat - & - & Moinga. \\
\hline & & - Masanga. & Moon & - & - Marama. \\
\hline Black - & - & . Belaa. & Mosquito & - & - Namu. \\
\hline Blood & . & - Makana. & Mother & - & - Kina'a. \\
\hline Boat - & . & - Sevaka. & Mouth & . & - Laungoku? \\
\hline Body & - & - Kigokama. & Night & - & - Bo. \\
\hline Bone - & 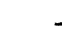 & - Heivi. & Nose - & . & - Aisu. \\
\hline Butterfly & . & - Pepele. & Pig & - & - Boe. \\
\hline Child - & - & - Kamali lii Kamari. & Rain - & - & - Ua. \\
\hline Coconut & - & - Niu. & Rat & - & - Heiore. \\
\hline Cold - & - & - Samalio. & Red & - & - Mea. \\
\hline Dog & - & - Po-e. & Salt & - & - Lokai. \\
\hline Door - & & - Puikakoa. & Sea - & - & - Peau. \\
\hline Ear & - & - Caringa. & Skin & - & - Ingi. \\
\hline Egg & . & - Hua. & Smoke & - & - Ohu. \\
\hline Face & - & - Meisu. & Spittle & - & - Savari. \\
\hline Futher & - & - Kamana. & Star - & - & - Feku. \\
\hline Finger & - & - Makalima. & Sun & & - Selaa. \\
\hline $\begin{array}{l}\text { Fire - } \\
\text { Fish }\end{array}$ & . & $\begin{array}{l}\text { Feafi. } \\
\text { - Ia. }\end{array}$ & \multicolumn{2}{|c|}{ Taro (two varieties) } & $\begin{array}{l}\text { Apoli'i and Saupu- } \\
\text { lapula. }\end{array}$ \\
\hline Fishhook & - & - Makav. & \multicolumn{2}{|c|}{ Tattooing hammer } & - Heli'i. \\
\hline Fly - & - & - Lango. & 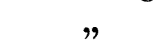 & needle & - Makao. \\
\hline Fowl - & - & - Moa. & Tongue & - & - Lelo. \\
\hline Frigate-bird & & - Akaha. & Tooth & - & - Nifu. \\
\hline Good & & - La-ui. & Turtle & - & Masanga. \\
\hline Hair & - & - Ulu. & Water & - & - Vai. \\
\hline Hand - & - & - Lima. & Whale (Sp & erm) & Kalıora. \\
\hline Head & & - Poulu. & White & - & - Mainge. \\
\hline Hot - & - & - Oa. & Woman & & - Fafini. \\
\hline House & $\cdot$ & - Vare. & Yellow & - & - Felo. \\
\hline Large - & - & Lasi. & & & \\
\hline
\end{tabular}

Numerals.

1. Kasi.

2. Lua.

3. Koru.

4. Faa.

5. Lima.

6. Ono.

7. Hiku.

8. Varu.

9. Sivo.

10. Sangaholu.
20. Luahui.

30. Korungahui.

40. Faangahui.

50. Limangahui.

60. Onongahui.

70. Vikunagui.

80. Varungahui.

90. Sivonahui.

100. Quikarau.

1000. Simaka.

C. M. WOODFORD. 